\title{
Corporate Brand Management Imperatives: Custodianship, CredibiLITY, and Calibration
}

\author{
John M.T. Balmer
}

Marshaling case study research insights, this article advances our knowledge of the strategic management of corporate brands. Strategic corporate brand management requires commitment to three critically important imperatives: senior management custodianship; the building and maintaining of brand credibility; and the dynamic calibration of seven identities constituting the corporate brand constellation. This article draws on research dating back to the 1990s and is also informed by the identity-based view of corporate brands perspective and by recent scholarship on the AC ID Test - a strategic, diagnostic, corporate brand management framework. (Keywords: Brand management, Corporate strategy, United Kingdom, Brand equity, China, Communication in organizations, Corporate culture, Organizational change)

n recent times, senior executives have progressively become au courant with the strategic imperative of building strong and meaningful corporate brands. Senior managers increasingly realize that company brands are unique, portable, divestible, and highly valuable corporate assets. Corporate brands are a means of creating both shareholder and stakeholder value. For these reasons, CEOs and senior executives should become connoisseurs of corporate brand management. There can be considerable merit in scrutinizing the firm via a corporate branding lens. ${ }^{1}$

\section{Delineating the Corporate Brand}

A corporate brand is a distinct identity type pertaining to one or more entities. It has a quasi-legal character in that it is underpinned by an informal, albeit powerful, corporate contract between the firm and its stakeholders-a corporate brand "covenant". This covenant relates to the expectations customers and other stakeholders associate with a corporate brand name (and/or marque) and a firm's values and ethos vis-à-vis product and service quality. Whereas legal ownership 
of a corporate brand resides with a firm, emotional ownership - and thereby its real value-belongs to customers and other stakeholders. Successful corporate brands are meaningfully differentiated from others and are profitable to stakeholders and shareholders alike. Customers and other stakeholders can accept, adapt, reject, or be ambivalent to a brand covenant. The corporate brand

John M.T. Balmer is the Professor of Corporate Marketing, Brunel University, London, and quondam Professor of Corporate Brand/Identity Management at Bradford School of Management, UK. $\mathrm{He}$ is the founder/chairman of the International Corporate Identity Group Conference (ICIG).

$<$ John.Balmer@brunel.ac.uk> covenant emerges over time and, de facto, represents a synthesis of a firm's foremost corporate identity attributes. Corporate brands can be bought, sold, and borrowed by firms and can be owned (or shared) by multiple entities. Corporate brands are inextricably linked to corporate identities. Whereas the corporate brand covenant gives surety (what is promised), it is manifested by a firm's corporate identity (what is delivered).

Our research has uncovered three imperatives underpinning the strategic management of corporate brands:

- the brand custodianship imperative: ensuring the corporate brand is seen as a strategic senior management concern;

- the brand credibility imperative: ensuring the corporate brand covenant is bona fide; and

- the brand calibration imperative: ensuring the corporate brand covenant is meaningfully and dynamically aligned with the identities forming the corporate brand constellation.

\section{The Reassurance, Emotional, and Financial Value of Corporate Brands}

Successful corporate brands are sought after by customers and other stakeholders alike. Corporate branding aficionados appreciate that successful corporate brands imbue institutions with considerable leverage because of the positive assurances that are linked to the company name. These assurances can, in addition, have an additional emotional value for stakeholders and can have an added financial value to institutions because of the brand equity element accorded to the corporate brand as a stand-alone strategic resource (see Table 1). For instance, the economic theory of the resource-based view of the firm has been applied to successful corporate brands in order to reveal why they are key institutional assets. ${ }^{2}$ In addition, a stakeholder's sense of identification with the brand can be strong and stakeholders may intrinsically and emotionally feel they have proprietary ownership of the brand. This can be especially strong among brand communities of customers: the Harley-Davidson motorbike brand is a prime example. ${ }^{3}$

\section{The Case of the Chinese Corporate Brand Haier}

Increasingly, the organizational and strategic efficacy of corporate brand building has begun to take hold in emerging markets. For instance, in China, the white-goods corporate brand Haier, has long-recognized the strategic importance 
TAB LE I. The Reassurance, Emotional and Financial Value of Successful Corporate Brands

\begin{tabular}{|c|c|c|}
\hline $\begin{array}{l}\text { Corporate Brand } \\
\text { Assets }\end{array}$ & Explanation & Brand Example \\
\hline Reassurance Value & $\begin{array}{l}\text { Successful corporate brands are } \\
\text { coveted by stakeholders and } \\
\text { institutions alike. Over many years } \\
\text { trust is accrued to successful corporate } \\
\text { brands as a stand-alone identity type } \\
\text { (separate and divisible from corporate } \\
\text { identity). The reassurance value of } \\
\text { corporate brands to stakeholders } \\
\text { translates into institutional value: a } \\
\text { firm's purposes for its existence can } \\
\text { be realized via the corporate brand. }\end{array}$ & $\begin{array}{l}\text { Haier } \\
\text { (over a } 30 \text { year period the brand } \\
\text { building efforts of Haier have caused } \\
\text { it to become an established and } \\
\text { trusted corporate global brand: one } \\
\text { of the first to emerge from the } \\
\text { People's Republic of China) }\end{array}$ \\
\hline Emotional Value & $\begin{array}{l}\text { Stakeholders sometimes have a } \\
\text { strong personal bond with the } \\
\text { corporate brand. Customers, and } \\
\text { other stakeholders, may feel they } \\
\text { have emotional ownership of the } \\
\text { corporate brand }\end{array}$ & $\begin{array}{l}\text { Body Shop } \\
\text { (from its modest beginnings in } \\
\text { Brighton, England, Dame Anita } \\
\text { Roddick's socially responsible } \\
\text { company metamorphosed into a } \\
\text { much-loved ethical corporate brand } \\
\text { on the global stage) }\end{array}$ \\
\hline Financial Value & $\begin{array}{l}\text { Successful corporate brands can be } \\
\text { bought, sold and borrowed by firms. } \\
\text { The economic value of corporate } \\
\text { brands may materially enhance } \\
\text { shareholder value in the short-term } \\
\text { (dividends) and long-term (the brand } \\
\text { equity element associated with the } \\
\text { corporate brand name/marque) }\end{array}$ & $\begin{array}{l}\text { Marriott } \\
\text { (the leasing of the Marriott corporate } \\
\text { brand, via franchising arrangements, } \\
\text { is a highly lucrative pecuniary activity } \\
\text { of this U.S.-based hotel group) }\end{array}$ \\
\hline
\end{tabular}

in building a successful and clearly defined corporate brand. Thirty years ago, Haier was a failing refrigeration manufacturer whose products were known more for their inferiority rather than their quality. It was Haier's CEO Zhang Ruimin who, in 1984, initiated an ambitious four-stage growth strategy that aimed to position Haier as a credible and global corporate brand. Initially, the firm's strategy focused on brand building in the China's hinterland, but Ruimin's strategy was to achieve, within a thirty-year time frame, global prominence in the white goods market. The focus for each stage of Ruimin's four part grand stratagem was: brand building, diversifying, globalizing, and global branding. The strategy worked. Today, Haier is the world's largest-seller of domestic appliances. Significantly, Haier is one of the first truly (and moreover truly trusted) global brands to have emerged from the People's Republic of China. ${ }^{4}$

\section{The Challenges and Responsibilities of Strategic Corporate Brand Management}

Strategic corporate brand management, maintenance, and development should be recognized as being critical, challenging, and ceaseless boardroom concerns. Senior managers also need to comprehend the challenges and responsibilities that come with 
corporate brand management. Responsibilities include the upkeep of a meaningful corporate brand covenant (the positive assurances associated with the brand name). Failure to effectively nurture a corporate brand may cause the brand to lose its luster with customers and other stakeholders and may result in the brand emerging as an institutional liability. By focusing on the three corporate brand management imperatives of custodianship, credibility, and calibration, senior managers are better placed to meet the tasks and challenges of strategic corporate brand management.

\section{Corporate Brands: An Overview}

Based on the theoretical perspective of identity-based views of corporate brands, there are seven identity types in the corporate brand constellation that underpin the $\mathrm{AC}^{4} \mathrm{ID}$ Test framework. ${ }^{5}$ In terms of the corporate brand calibration imperative, the $\mathrm{AC}^{4} \mathrm{ID}$ Test is significant.

\section{The Covenanted Corporate Brand Identity: What is it?}

A corporate brand (the covenanted identity) is a distinct identity type. Although derived from a firm's corporate identity, a corporate brand covenant is a synthesis of the firm's key, and long-standing, corporate identity attributes that have emerged over time. Corporate brands can have lives of their own: a brand identity that is divisible from the corporate identity from which it emerged.

For example, many decidedly British corporate brands-brands that have an enviable British provenance and are conspicuously British in terms of their corporate brand covenants-are owned by corporations outside the UK. The notion of British brands that are in overseas ownership affords one insight why corporate brands can be a strategic resource and can have a life of their own.

Consider the U.S.-based Carnival Corporation. Carnival owns two celebrated British ocean lines, P\&O Cruises Limited and the Cunard Line Limited. The P\&O brand (originally known as the "Peninsular and Oriental Steam Navigation Company") dates back to 1837 and was the premier line linking Britain and its imperial territories. It pioneered the concept of cruise vacations and remains a prominent player. Cunard has the unique distinction of having a scheduled transatlantic passenger service between New York and Southampton. As the most celebrated luxury cruising brand-burnished by its renowned Royal associations (all of its ships are named after British Queens) - it is a corporate heritage brand without parallel on the high seas. Cunard is the epitome of traditional British style and sophistication.

Consider, too, the British automotive corporate brands: Bentley, Jaguar Land Rover, MG, Rolls Royce, and Vauxhall. All have been acquired by foreign corporations for strategic reasons and today are subsidiary companies of German (Bentley and Rolls Royce), Indian, Chinese, and U.S. corporations respectively, although they all still maintain their distinctive British attribution.

Guided by the brand covenant, stakeholders can more fully discern what a brand stands for and may more readily appreciate how a brand is differentiated. The bi-lateral corporate brand covenant provides a reassurance vis-à-vis corporate behavior, ethos, values, and product and service quality. Stakeholders can create 
their own brand meanings and may determine the type of associations they wish to have with a particular corporate brand. They can accept, adapt, reject, or, indeed, be ambivalent to a corporate brand covenant. It is important for managers to be apprised of customers', employees', and other stakeholders' conceptualizations of the corporate brand. Sometimes, the very nature of the corporate brand promise can be partly shaped by these insights. However, senior managers should not only be guided by stakeholders' perception of their corporate brand, they must also take into account of the attributes of the firm (the corporate identity) that accord the brand credibility. The $\mathrm{AC}^{4} \mathrm{ID}$ Test-elucidated below-takes account of this. ${ }^{6}$

\section{The Covenanted Corporate Brand Identity: What of its value?}

Successful corporate brands can also be invested with a financial value as stand-alone resources: the brand equity dimension. Importantly, this financial asset can be turned into a liquid asset when the brand is acquired, and leveraged, by another firm. Moreover, company brands can be a valuable income stream for institutions when the inherent brand values and reassurances are borrowed by other firms. The brand can be licensed to another firm for a short period (as in the case of IBM vis-à-vis Lenovo) or, more usually today, loaned via mutually lucrative franchising arrangements. ${ }^{7}$

Consider Lenovo, a once comparatively little-known Chinese computer manufacturer, which in 2005 propelled itself on to the international stage as a global corporate brand. Lenovo paid $\$ 1.75$ billion for IBM's personal computer business and, importantly, secured the rights to use the IBM brand for five years. Through its close association with IBM, Lenovo was able to enhance its corporate brand profile and trust on the global stage. This is because the IBM brand, in the early stages of the agreement, served as an implicit endorsement of the Lenovo corporate brand. The success of this initiative resulted in Lenovo dropping its use of the IBM brand after two years. Why? Because within that time scale, the Lenovo corporate brand covenant was understood, was widely trusted, and had managed to leverage its brand's value. ${ }^{8}$

Finally, the scope and significance of the franchising of corporate brands as a strategic activity should not be underestimated. For some organizations, corporate brand franchising is a highly lucrative business endeavor and competency. Consider the Subway corporate brand. Founded in 1965 by Fred DeLuca in Connecticut, Subway adopted a franchise business model in 1974. Today the brand is a successful multi-billion dollar business and its corporate brand is to be found in 36,345 restaurants in 98 countries. ${ }^{9}$ Franchising is particularly prevalent in the hotel sector where corporate branding franchising-along with corporate brand franchising coupled with management-is common. The owners of many prominent hotel brands actively eschew hotel ownership, and where ownership does exists it is often on an extremely limited scale. For instance, the U.S. hotel brand Marriott owns a mere six of its 3,400 branded hotels. An analogous example is the British-based InterContinental (IC) hotel brand. Of its 4,443 branded hotels only 12 are owned by IC, less than $1 \%$ of its portfolio. ${ }^{10}$ 
From a corporate brand management perspective, multiple firms align their corporate identities so that they are meaningfully and seamlessly aligned with a corporate brand covenant-one covenant, but delivered by numerous corporate identities. The Subway, Marriott, and InterContinental brands are prime examples of this. Senior managers need to take account of both the corporate brand and the corporate identity as linked, distinct, and significant identity types.

\section{The Corporate Brand Constellation: Identity-Based Views of Corporate Brands}

The importance of recognizing the value of multiple identities as a collective can be of considerable consequence to senior executives. Seven identities are identified as being meaningful to what we call the corporate brand constellation and to the diagnostic branding framework ${ }^{11}$ - the $\mathrm{AC}^{4} \mathrm{ID}$ Test-detailed latter on. The initial letters of the seven identity types-as will be apparent-constitute the acronym $\mathrm{AC}^{4} \mathrm{ID}$. Since its initial conceptualization in 1999, the ACID Test has undergone several adaptations and refinements. ${ }^{12}$ The current version comprising seven facets (The $\mathrm{AC}^{4} \mathrm{ID}$ Test) dates back to 2005. Table 2 details the seven identity types of the corporate brand constellation and enumerates the characteristics of each identity type.

TAB LE 2. The Corporate Brand Constellation (informs the $A C^{4} I D$ Test of Corporate Brand Management)

\begin{tabular}{|c|c|c|c|c|}
\hline Identity Type & $\begin{array}{l}\text { Critical } \\
\text { Concern }\end{array}$ & Responsibility & Concept & Timeframe \\
\hline$\underline{\text { Actual Identity }}$ & $\begin{array}{l}\text { What the company's } \\
\text { identity indubitably is a }\end{array}$ & $\begin{array}{l}\text { CEO \& Senior } \\
\text { Executives }\end{array}$ & Corporate Identity & Present \\
\hline $\begin{array}{l}\text { C'ommunicated } \\
\text { Corporate Brand } \\
\text { Identity }\end{array}$ & $\begin{array}{l}\text { What the company/ } \\
\text { companies }{ }^{b} \text { claims the } \\
\text { corporate brand to be }\end{array}$ & $\begin{array}{l}\text { Corporate } \\
\text { Communications } \\
\text { Managers }\end{array}$ & $\begin{array}{l}\text { Corporate Brand } \\
\text { Communications }\end{array}$ & Past/Present/Future \\
\hline $\begin{array}{l}\mathbf{C}^{2} \text { onceived } \\
\text { Corporate Brand } \\
\text { Identity }\end{array}$ & $\begin{array}{l}\text { What the corporate } \\
\text { brand is seen to be } \\
\text { (by stakeholders) }\end{array}$ & $\begin{array}{l}\text { Corporate } \\
\text { Marketing } \\
\text { Managers }\end{array}$ & $\begin{array}{l}\text { Corporate Brand } \\
\text { Image }\end{array}$ & Past/Present \\
\hline $\begin{array}{l}\mathbf{C}^{3} \text { ovenanted } \\
\text { Corporate Brand } \\
\text { Identity }\end{array}$ & $\begin{array}{l}\text { What the company's } \\
\text { brand promises to be }\end{array}$ & $\begin{array}{l}\text { CEO \& Corporate } \\
\text { Marketing } \\
\text { Managers }\end{array}$ & Corporate Brand & Past/Present \\
\hline $\begin{array}{l}\mathbf{C}^{\mathbf{4}} \text { ultural } \\
\text { Corporate Brand } \\
\text { Identity }\end{array}$ & $\begin{array}{l}\text { What the (internal) } \\
\text { corporate brand values } \\
\text { are found to be }\end{array}$ & $\begin{array}{l}\text { Managers \& } \\
\text { Employees }\end{array}$ & $\begin{array}{l}\text { Corporate Brand } \\
\text { Culture }\end{array}$ & Past/Present \\
\hline $\begin{array}{l}\text { Ideal Corporate } \\
\text { Brand Identity }\end{array}$ & $\begin{array}{l}\text { What the corporate } \\
\text { brand needs to be }\end{array}$ & Strategic Planners & $\begin{array}{l}\text { Corporate Brand } \\
\text { Strategy }\end{array}$ & Future \\
\hline $\begin{array}{l}\text { Desired Corporate } \\
\text { Brand Identity }\end{array}$ & $\begin{array}{l}\text { What the CEO/Senior } \\
\text { Executives wishes the } \\
\text { corporate brand to be }\end{array}$ & $\begin{array}{l}\text { CEO \& Senior } \\
\text { Executives }\end{array}$ & $\begin{array}{l}\text { CEO's/Senior } \\
\text { Managers' } \\
\text { Corporate Brand } \\
\text { Vision }\end{array}$ & Future \\
\hline
\end{tabular}

\footnotetext{
a Refers to the institutional attributes of a firm-its corporate identity-those organizational dimensions that in strategic terms imbue a firm with distinctiveness, differentiation and desirability

${ }^{b}$ Some corporate brands are owned by more than one company viz: Rolls Royce. In an analogous fashion The British Monarchy shares its head of state (ergo its iconic national brand) with 15 other countries each of whom regards H.M. Queen Elizabeth II as their Head of State (one brand-16 brand owners).
} 


\section{The Research}

The findings reported here are primarily informed by multiple in-depth clinical case study research dating back to the 1990s. Marshalling these research insights, this article synthesizes these revelatory case studies in order to explicate the nature, significance, and normative insights vis-à-vis corporate brand management. These studies were employed a case study methodology ${ }^{13}$ under- $^{-}$ taken within the inductive research tradition using qualitative data. ${ }^{14}$ Data was typically collected via in-depth interviews with senior managers along with the examination of company documents. Data was cross-checked by means of triangulation. The British Airways case study is a both a revelatory as well as a longitudinal case study of the airline, covering a twenty-year period 19802000. The British Monarchy case study draws on research relating to monarchies as corporate brands, which dates back to 2001. In terms of the ACID Test framework, this draws on research dating back to the 1990s. The model grew out of a substantive stream of research undertaken in the U.S. and UK and was informed by data collected from prominent corporate brand consultancies. It has been revised several times. The version of the ACID test framework detailed here has been informed by senior manager insights-in terms of its application-from a variety of organizations. Certain examples cited in this article are informed by secondary data viz: Coca-Cola, Apple, and London Transport.

\section{Corporate Brand Management Imperatives: Custodianship, Credibility, and Calibration}

From this research, three corporate brand management imperatives became evident. Senior managers can be guided by these imperatives in order to strategically manage their corporate brands.

- custodianship (guarding and managing the corporate brand covenant; the notion of semper fidelis)

- credibility (living and realizing the corporate brand covenant; a modus vivendi)

- calibration (a method for sustaining and changing the corporate brand covenant; a modus operandi)

The corporate brand custodianship imperative is a recognition that corporate brand management is an ongoing strategic senior management responsibility. The corporate brand credibility imperative requires the brand covenant to be enacted via the firm's activities and values. It is a corporate branding modus vivendi-a way of living the brand. Finally, the corporate brand calibration imperative takes account of the many bi-lateral relationships between the corporate brand identity and the other identity modes. It can be viewed as an auxiliary imperative since it buttresses credibility. It is a way of managing the corporate brand-a modus operandi. An overview of these perspectives and the case examples research elucidate each imperative (as shown in Table 3). 
TABLE 3. Corporate Brand Imperatives

\begin{tabular}{|c|c|c|c|}
\hline $\begin{array}{l}\text { Corporate } \\
\text { Brand } \\
\text { Imperative }\end{array}$ & Rationale & Explanation & $\begin{array}{l}\text { Examples } \\
\text { Cited in } \\
\text { Article }\end{array}$ \\
\hline Custodianship & $\begin{array}{l}\text { Building, guarding and } \\
\text { managing the } \\
\text { corporate brand } \\
\text { covenant }\end{array}$ & $\begin{array}{l}\text { Corporate brands are a senior/CE) } \\
\text { management responsibility: they are } \\
\text { critically important (strategic) assets. } \\
\text { Executives should always be faithful to } \\
\text { the precept of semper fidelis, } \\
\text { demonstrating on-going fidelity to } \\
\text { corporate brand stewardship. }\end{array}$ & $\begin{array}{l}\text { London Transport } \\
\text { Apple }\end{array}$ \\
\hline Credibility & $\begin{array}{l}\text { Living and realizing } \\
\text { the corporate brand } \\
\text { covenant }\end{array}$ & $\begin{array}{l}\text { Corporate brand credibility is dependant } \\
\text { on an organizational-wide adherence to } \\
\text { a corporate brand/corporate marketing } \\
\text { philosophy and a cultural modus vivendi. } \\
\text { As such the corporate brand covenant } \\
\text { being authentic (reflects the firm's } \\
\text { identity), believable (reflects the firm's } \\
\text { culture); durable (sustainable), profitable } \\
\text { (of value to stakeholders), and, } \\
\text { responsible (meeting the firm's CSR and } \\
\text { ethical responsibilities. }\end{array}$ & $\begin{array}{l}\text { British Airways } \\
\text { BP }\end{array}$ \\
\hline Calibration & $\begin{array}{l}\text { Sustaining and } \\
\text { changing the } \\
\text { corporate brand } \\
\text { covenant }\end{array}$ & $\begin{array}{l}\text { Corporate brand calibration is } \\
\text { a method-a modus operandi-by } \\
\text { which credibility can be attained and } \\
\text { maintained in the present (corporate } \\
\text { brand being), in the future (corporate } \\
\text { brand becoming) and in both the } \\
\text { present and future (corporate brand } \\
\text { bridging). The AC ID Test framework } \\
\text { affords assistance to senior executives } \\
\text { in their strategic task of calibrating the } \\
\text { covenanted corporate brand identity } \\
\text { with other identity types. }\end{array}$ & $\begin{array}{l}\text { Coca-Cola } \\
\text { Hilton } \\
\text { Co-operative Bank } \\
\text { The British } \\
\text { Monarchy }\end{array}$ \\
\hline
\end{tabular}

\section{Corporate Brand Malady and Mortality}

Sometimes senior managers can do little to prevent branding maladies or to protect a brand from irreparable, sometimes sudden, decline. Brand malady and mortality should always be expected and planned for; corporate brand longevity is the exceptions rather than the rule. Changes in the business environment, such as the advent of new technologies, can conspire to severely weaken a brand and sometimes shorten its life.

Consider the largely long-forgotten pioneering British-based aircraft manufacturer De Havilland. De Havilland is credited with the design and development of the first passenger jet aircraft. Yet its corporate brand failed to take-off because it lacked a strong customer/marketing orientation. For instance, its relatively small, albeit leading-edge, planes were ill-suited to the needs of airlines. Whereas De Havilland had the skills of invention and production, ultimately it was to be the marketing-orientation and the financial and business acumen of Boeing and 
Douglas in the U.S. that would triumph. These U.S. firms eclipsed what should have been the first-mover advantage of De Havilland. ${ }^{15}$

The death-knell can be rung even for established corporate brands, including those invested with an enviable heritage and tradition and which seem to be sustained by unassailable stakeholder loyalty. Yet, when confronted with challenger corporate brands whose products are demonstrably cheaper and in performance terms superior, established brands can flounder and fail. Consider the UK motorbike sector. During the 1950s, Great Britain could boast a number of illustrious motorbike marques such Norton, Triumph, and Vincent. However, the keen pricing and premium performance of Japanese brands meant that by the 1980s the pre-eminent brands in the sector were from Japan: Honda, Yamaha, and Suzuki. ${ }^{16}$

Sometimes, some corporate brands are so fatally damaged that they disappear altogether, such as the British Townsend Thorsten shipping brand. The derisory standards of safety that were prevalent in the company caused the worst tragedy in Britain's maritime history since the sinking of the Titanic. In 1987, 193 passengers perished when the Herald of Free Enterprise ferry capsized off the Belgium coast. The scale of the tragedy damaged the brand to the point of rendering it unsalvageable. ${ }^{17}$

More recently, in 2011, in the wake of widespread condemnation from the public, police, politicians, regulators, and advertisers, the 168-year-old Londonbased News of the World newspaper brand was euthanized. Reports of unethical telephone hacking and allegations of payments of \$160,000 in bribes to policemen by News of the World journalists followed earlier corporate misdemeanors, including the phone hacking of members of the Royal Family, which resulted in the prosecution of the paper's royal editor in 2007. While it is uncertain whether the newspaper could have survived the imbroglio and while there might have been ulterior motives on the part of the paper's owners (News International), it is clear that the brand had been severely undermined. ${ }^{18}$ As London's Financial Times noted, The News of the World brand had become so toxic that it was worth more to its owners dead than alive. ${ }^{19}$ Where a firm's ethos and culture seriously jars with societal values, there can be long-term corporate brand damage.

\section{First Corporate Brand Imperative: Custodianship}

\section{Guarding and Managing the Corporate Brand "Semper Fidelis"}

The exigencies of corporate brand custodianship require company brands to be managed with consummate care and consideration by senior executives. Guided by the precept "semper fidelis" (always faithful), senior managers must show fidelity to the corporate brand. Since corporate brands are of strategic importance, they need to be an indelible component of a firm's ongoing strategic deliberations.

Taking a business history perspective, the success of many corporate brands has, in part, been attributable to the attention accorded to corporate branding and identity issues by their CEOs. As the corporate branding savant Douglas Hyde (the CEO of OshKosh B'Gosh, a leading children's clothing brand in the U.S.) 
remarked: "When the company and the product image are one and the same, it is paramount that the CEO be the brand manager."

Hyde's reflection especially pertains to the work of London Transport's (LT) first, and legendary, Chief Executive Frank Pick. ${ }^{20}$ Today, London Transport has a highly distinctive, globally recognized, enduring, and treasured corporate brand. LT's greatly fêted logo (the roundel), its celebrated "Routemaster" double-decker buses painted in LT's distinctive imperial-red bus livery, and LT's venerated schematic underground map all have an incontrovertible emblematic status. They are powerful brand icons: not only for LT, but for London as well. However, the corporate identity and corporate branding challenges confronting Pick back in 1933 with the establishment of LT were gargantuan. As LT's first CEO, Pick was charged with the task of fashioning a new identity from the myriad types of firm that came under LT's control. This included 4 municipal and 3 privately owned tramways, 5 railroad firms, 66 bus and coach companies, and an assortment of transportation services operated by no-less-than 69 other organizations. Responsibility for the design of buses, trains, and stations also fell within his purview. Pick-following an innate corporate marketing logic-realized that new corporate purpose, culture, and values had quickly to be fashioned for the corporate entity and for its 70,500 employees. Pick met the challenges in shaping a new identity through his pursuance of an organization-wide customer-orientation, the fostering of high standards of service, and the nurturing of staff loyalty and identification with LT. Notably, Pick also established a clear corporate marketing design ethic. He realized, too, that a unified visual identification scheme could be efficacious in meeting the organization's purpose: not only was it a business tool to unite the organization, but it had the important role of communicating LT's customer orientation and the scope of the integrated transportation system for the entire metropolis. Under Pick's vigilant stewardship, LT's identity attributes quickly coalesced to meaningfully inform what became an inimitable corporate brand covenant for London Transport.

In recent times, one prominent exemplar of the custodianship imperative is the Apple corporate brand. Under the astute stewardship of the late Steve Jobs, the Apple corporate brand was infused with a strong marketing/consumer orientation and was suffused with peerless design values as well. The corporate brand covenant of Apple was such that customers expected the corporate brand's products to meet-and even surpass - their needs. There was an expectation, too, that there would be ease of use of Apple's products. In addition, the corporate brand covenant of Apple gave the reassurance that the firm's products would, in addition, be infused with design creativity, perfection, and practicality. It was an institutional brand that molded the tastes of millions globally and fashioned digital industries generally. Hardly surprising, then, that Apple has engendered a fanatical, sometimes religious-like, loyalty from many within Apple's corporate brand community. Perhaps, then, it is no surprise that Apple has regularly been voted as one of the most innovative companies on the international stage. Moreover, it has become the world's most valuable brand. ${ }^{21}$

Clearly, the design, marketing, and quality standards demanded of Steve Jobs materially informed Apple's corporate brand covenant: a brand promise that 
TAB LE 4. A Comparison Between Product and Corporate Brands

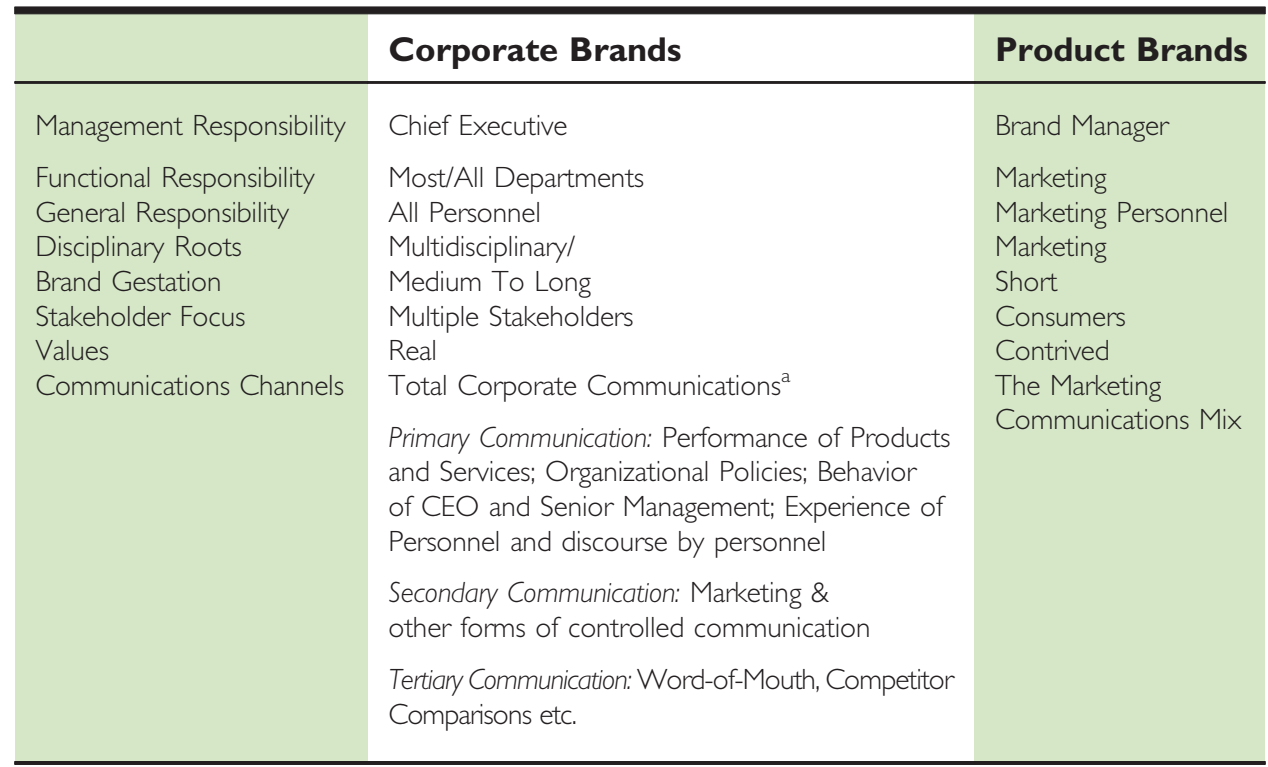

${ }^{a}$ The Total Corporate Communications Framework can be found at J.M.T. Balmer and E.R. Gray, "Corporate Identity and Corporate Communications: Creating a Competitive Advantage," Corporate Communications: An International Journal, 4/4 (1999): 175.

was readily transparent to all. The exacting standards that the Apple brand promised materialized into what was expected by Apple's stakeholders. Internally, within Apple, it underpinned what needed to be attained and maintained by Apple's managers and employees. Learning from this, it is imperative for senior managers to a have a firm grasp of their covenanted identity in terms of what the corporate brand stands for, the meanings stakeholders ascribe to it, and the emotions and individual identities stakeholders draw from it.

Senior managers need to appreciate that whereas corporations have legal ownership of corporate brands, the real value of corporate brands are derived from their emotional ownership by customers and other stakeholders. Apple is an exemplar of this. Corporate brands must be managed with considerable care, consideration, and creativity. It is also important for top executives to appreciate how corporate brands and their management differ from product brands and their management (see Table 4).

Furthermore, the complexities and opportunities afforded by corporate brands in terms of architecture can also be informative in strategic terms. It is important for senior managers to be appraised of new modes of brand relationships that characterize corporations (see Appendix A).

\section{Second Corporate Brand Imperative: Credibility}

\section{Living the Corporate Brand "A Modus Vivendi"}

It is the responsibility of senior executives to ensure that the corporate brand covenant is, and remains, meaningful to customers and other stakeholders. Of course, it should also be beneficial to the firm in meeting its business objectives. 
Therefore, it is de rigueur for senior executives is to ensure their corporation's corporate brand positioning is acceptable (reflects corporate identity), believable (underpinned by the firm's cultural values); durable (expected to endure); profitable (of benefit to customers and other stakeholders); and responsible (takes account of its ethical and CSR concerns). These are detailed in Table 5.

Internally, credibility entails "living the brand promise"-in short, it is a modus vivendi (a way of living). The espoused corporate brand promise should be bona fide in terms of the organization's purposes, activities, products and services, and culture. For this to be achieved, employees need to understand, support, and, moreover, demonstrate to other stakeholders a common adherence to corporate brand values.

This modus vivendi has a great chance of being realized if it is underpinned by an organizational-wide corporate marketing philosophy (a way of thinking) and culture (values which determine a way of behaving). The corporate marketing ethos recognizes that institutional identities and corporate brands per se-and not just products and services_-can be critical points of advantage and differentiation. This new philosophy is characterized by customer/stakeholder mutuality, organizational intentionality, shareholder sensibility, societal and ethical morality, and, of course, organizational legality. Organizations are social and political entities as well as economic entities. ${ }^{22}$ A corporate marketing logic helps to actualize the corporate brand promise and reinforces the notion that organizational members share responsibility for a corporate brand and corporate marketing orientation. Only then can a brand promise remain ongoing reality to customers, employees, and other stakeholders.

As the following quotes testify, the recent travails within the financial services sector reflect the importance of maintaining corporate brand/corporate marketing values and, of course, upholding a corporate brand's credibility. ${ }^{23}$ One former director of the former British-based Halifax Building Society reflected: "The clash of cultures between the stable, even staid, world of traditional mortgage lending and the risk-taking culture of wholesale banking brought the Halifax down. The pursuit of shareholder value damaged both shareholder value and the business. We let them all down." Customers also voiced their disquiet-and in some instances anger-towards the injudicious activities of senior managers: "The Dunfermline Building Society used to be a trusted and respected brand on Scottish high streets, but not any more. The arrogance and greed displayed

TAB LE 5. Corporate Brand Credibility Criteria

\begin{tabular}{l|l}
\hline Acceptable & $\begin{array}{l}\text { Reflects a firm's corporate identity (a corporate brand promise which is realistic and is } \\
\text { derived from an organization's distinctive identity attributes which of themselves are } \\
\text { believable, durable, profitable and responsible) }\end{array}$ \\
$\begin{array}{l}\text { Believable } \\
\text { Durable }\end{array}$ & $\begin{array}{l}\text { Expected to be endure and, prospectively, can be maintained over the long-term } \\
\text { Profitable }\end{array}$ \\
$\begin{array}{l}\text { Of strategic value to the firm and is of benefit to customers, shareholders and other } \\
\text { stakeholders }\end{array}$ \\
Responsible
\end{tabular}


by the building society is absolutely scandalous. They have been reckless with ordinary, hard-working people's money."

Arguably, credibility is the cornerstone of corporate brand management. All too quickly, the loss of brand credibility can mean that corporate brands lose their sheen, are weakened, and may even become a corporate liability. When brands become a problem, beneficial brand relationships with customers, employees, and business partners can be ruined, shareholder value damaged, and a company's growth stunted.

The recent histories of BP and British Airways are examples of corporations that have held corporate brand positions that are not credible. These cases illustrate what can go wrong when organizations that have devised corporate brand positioning initiatives that are creative, innovative and well-intentioned nonetheless fail the corporate brand credibility test.

\section{Credibility Loss: British Airways}

In 1996, in one of the most audacious corporate branding changes executed by a modern corporation in recent times, British Airways (BA) - the UK's legacy airline-repositioned the firm as an international rather than as a British company. The logic of the change was informed by research that revealed that two-thirds of BA's passengers were foreign. Underscoring this new brand positioning, BA adopted a new visual identity scheme, which rather than consisting of one visual identity now consisted of fifty tailfin symbols drawn from all corners of the globe. However, the airline failed to take into account that a key dimension of its corporate brand heritage was its strong, and positive, British associations. Moreover, in downplaying its British provenance and identity, the airline alienated many of its home passengers. Arguably, by adopting this new brand positioning, there was a failure to realize that the very Britishness of BA could be, in itself, a competitive advantage. Moreover, such a move would alienate BA's British travelers- $40 \%$ of all the airline's customers, many of whom paid premium prices for business class seats. In addition, the change would be censured by prominent figures such as former British Prime Minister Margaret Thatcher. The negative response to this branding initiative caused the airline to re-emphasize its British character and to express this through a pronounced British design vernacular. Gradually, the emphatic global positioning and international imagery were withdrawn. Reflecting on all this, Lord Marshall of Knightsbridge, a senior executive at BA, told us: "As it turned out, the airline had gone too far, too fast for its key stakeholders-customers, shareholders, employees-and the British public. The change was too drastic and in the view of many weakened the strength of our brand. There was also the perception that the proud heritage of British Airways was being swept under a carpet of modernization." ${ }^{24}$ It can be argued that British Airways brand positioning was not believable, durable, profitable, or responsible as per the credibility imperative.

\section{Credibility Loss: $\mathrm{BP}$}

The furor following the 2010 BP Deepwater Horizon debacle in the Gulf of Mexico resulted in widespread customer criticism, stakeholder condemnation, and state-censure of BP and its management by the U.S. President. Much of the 
furor focused on BP's safety record, operating practices, management, and the response of BP's CEO Tony Hayward. For a period, the very continuance of the BP marque was in question as the oil behemoth's share price plummeted. For some, BP was ripe for a take-over and it became a moot point when this would happen, who were the likely candidates, and how much would be paid. In the end, the BP brand endured.

As the maelstrom intensified, $\mathrm{BP}^{\prime} \mathrm{s}$ much trumpeted corporate brand positioning (a brand positioning that, since the turn of the century, celebrated the firm's commitment to a green and socially responsible corporate agenda) came under intense scrutiny. In a very high-profile manner, BP had underscored its green credentials via its corporate communications and especially though its new visual identity scheme. For instance, the visual branding scheme and brand positioning devised for BP by the U.S.-based corporate branding consultancy Landor resulted in the introduction of a striking new logo (a pastel and green shaded sunburst marque), and the rejection of its former corporate brand name British Petroleum. From now on the brand was to be simply knows as bp. Not only did bp chime with the brand's newly minted strap line "beyond petroleum" and mirror the new brand promise, it also reflected the new corporate reality. Whereas BP was a decidedly British organization, the new corporation (after its mergers with the U.S.-based Amoco and Arco companies) reflected a new institutional reality as a truly Anglo-American corporate entity. Moreover the brand marque reaffirmed the company's espoused sustainability stratagem. The use of the lower case bp was, in addition, significant. The objective was to express the wish that bp would, in the future, be decidedly less corporate in character. ${ }^{25}$

However, for some, BP's espousal of a CSR/green agenda appeared to be cynical, incredulous, and risible: it appeared to bear little resemblance to BP's way of living - its modus vivendi-and arguably was something akin to a dystopian deceit. Rather than green and CSR concerns informing BP's philosophy and culture, for some, the corporation's culture divulged a somewhat different narrative and revealed that BP has been primarily concerned with the driving down of costs and the pushing up of profits. Historically, BP's success has been attributed to a trailblazing spirit vis-à-vis oil exploration and, recently, to its daredevil pioneering spirit. ${ }^{26}$ One commentator inquired whether BP's culture prioritized profits at the expense of social responsibility and noted: “BP's culture allowed extreme short-sightedness in pursuit of profit at the cost of safety or environmental stewardship." 27 According to the British bon mot, death, taxation, and profits from BP are life's only certainties. Given the above, it is perhaps no surprise that in the aftermath of the catastrophe, there was widespread stakeholder opprobrium meted-out to the corporation and the BP brand forfeited a good deal of its trust, magnetism, and credibility.

Yet, back in 2001, BP's former CEO Lord Browne of Madingley told us that "without a clear business strategy, there can't be a clear and credible corporate brand. . . values which match strategy and which are expressed in performance." ${ }^{28}$ Tellingly, perhaps, in the period leading up to the catastrophe, a BP spokesman, reflecting on the corporation's brand positioning, said: "Our aspirations remain absolutely unchanged: no accidents, no harm to people, and no 
damage to the environment." 29 Yet, the dominant values within BP appear to reflect a culture that focused not so much on sustainability and ethics, but on profit maximization and risk (BP's pioneering spirit and daredevil ethos and culture). BP's culture and philosophy seemingly had little reference to its espoused corporate brand positioning but also jarred with societal values (as was seemingly the case with The News of the World newspaper).

\section{Third Imperative: Corporate Brand Calibration}

\section{Aligning the Corporate Brand: "A Modus Operandi"}

Corporate brand calibration-ensuring the brand constellation is dynamically aligned-is of material significance to senior executives. This is because it is a potent means by which corporate brand credibility can be maintained. Credibility should be assessed not only in terms of whether the corporate brand covenant is attuned with a firm's objectives and purposes, but whether it is in wide-ranging accord with the wants, needs, expectations, and even emotions of customers and other stakeholders.

Because of this, corporate brand calibration requires the corporate brand covenant to be appraised not only through the prism of the present, but also via the lens of the future. These temporal perspectives inform the $\mathrm{AC}^{4} \mathrm{ID}$ Test framework in its various permutations. A core precept of the framework is for there to be active, meaningful alignment with the covenanted corporate brand identity and the other six identities that constitute the corporate brand constellation (see Table 2). The $\mathrm{AC}^{4} \mathrm{ID}$ Test is a modus operandi by which this can be accomplished. In operationalizing the $\mathrm{AC}^{4} \mathrm{ID}$ Test, senior managers can be guided by the REDS ${ }^{2}$ diagnostic process detailed below. This is informed by the need for identityrevelation, identity-prioritization, and identity-intervention vis-à-vis corporate brand calibration.

\section{The $A C^{4} I D$ Test of Corporate Brand Management: The Corporate Brand Being Constellation, the Corporate Brand Becoming Constellation, and the Corporate Brand Bridging Constellation}

In this article, three versions of the $\mathrm{AC}^{4} \mathrm{ID}$ Test are outlined. Taking a time-based perspective, each version of the test-termed a constellation-aims to be of utility in meeting the varying strategic needs of senior executives in relation to corporate brand calibration. The three versions of the $\mathrm{AC}^{4} \mathrm{ID}$ Test are respectively called Corporate Brand Being, Corporate Brand Becoming, and Corporate Brand Bridging. Earlier versions of the $\mathrm{AC}^{4} \mathrm{ID}$ Test were informed by a centrifugal rationale. Multiple identity types should be in alignment with each other. The $\mathrm{AC}^{4} \mathrm{ID}$ Test framework outlined here is underpinned by a centripetal logic. Here, the multiple identity types are required to be calibrated with the covenanted identity. Another difference with the latest model is that greater cognizance is accorded to the temporal dimension. For this reason, the framework has been adapted to cover the future as well as present time frames. Figures 1, 2, and 3 illustrate the identities that inform each version and clearly illustrate the centripetal nature of the $\mathrm{AC}^{4} \mathrm{ID}$ Test in its various temporal permutations. Ideally, all 
FIGURE I. Corporate Brand Being Constellation

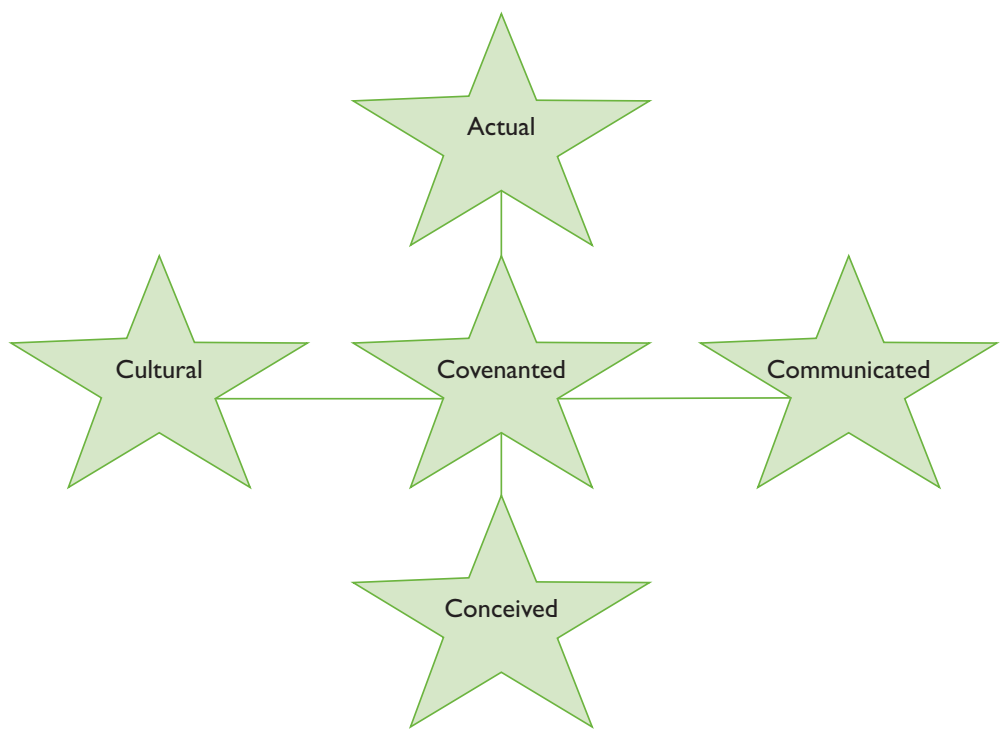

Adopting a centripetal approach, focusing on the current time frame, this simplified version of the corporate brand constellation shows the four tangential identity types requiring calibration with the covenanted identity. ( ) J. Balmer 2012.

Note: the three corporate brand constellation frameworks first appeared in: J.M.T Balmer, "Corporate Brands: A Strategic Management Framework," Bradford University School of Management, Working Paper No. 05/43, 2005.

FIGURE 2. Corporate Brand Becoming Constellation

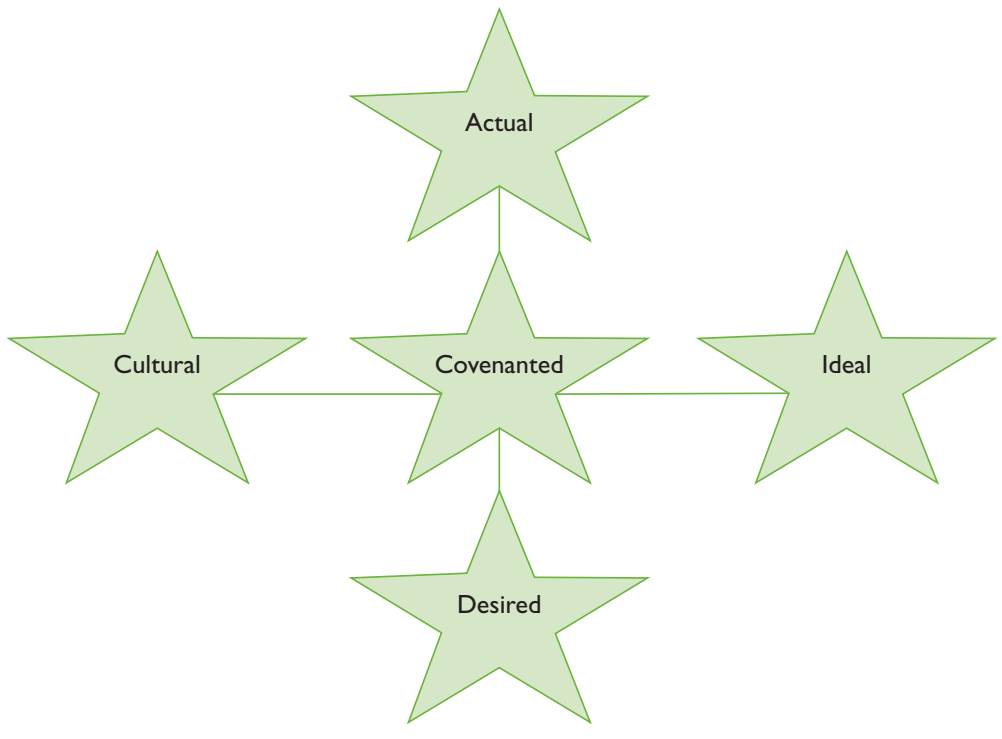

Adopting a centripetal approach, focusing on the future time frame, this simplified version of the corporate brand constellation shows the four tangential identity types requiring calibration with the covenanted identity. (c) J. Balmer 2012. 
FIGURE 3. The Corporate Brand Bridging Constellation

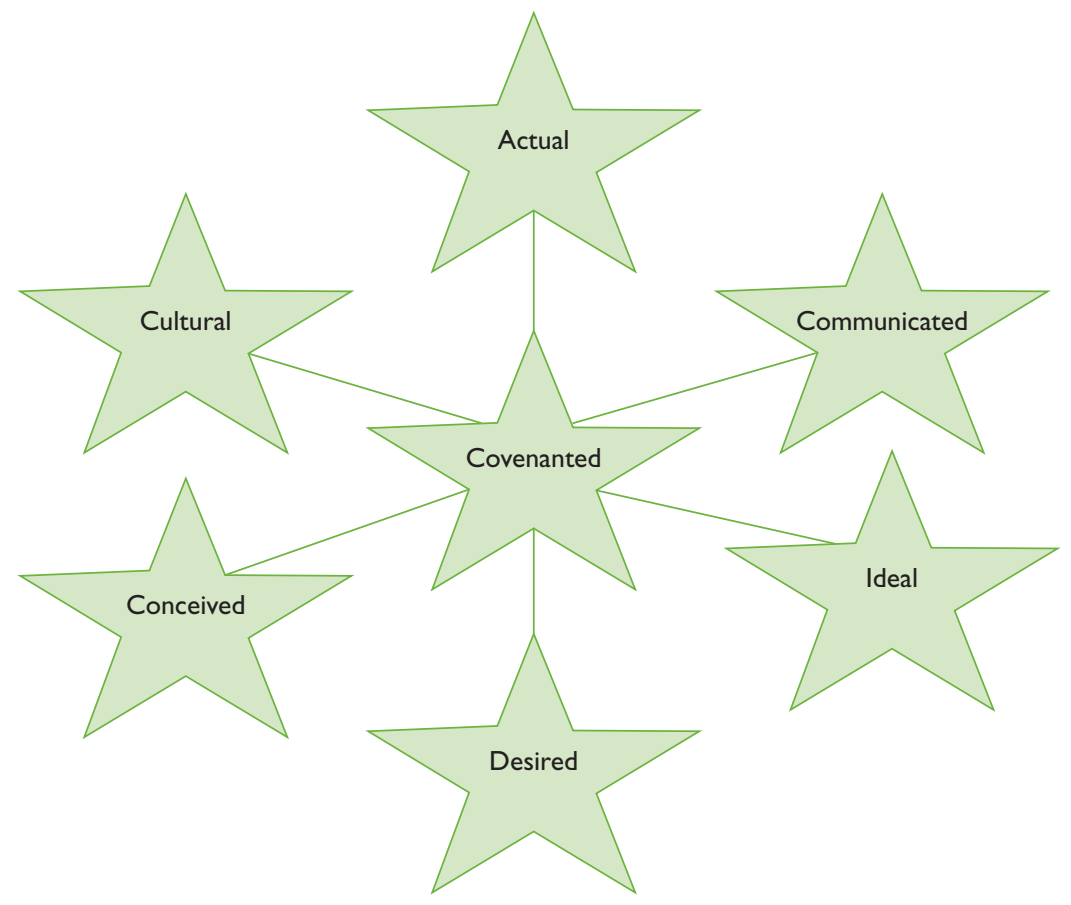

Adopting a centripetal approach, focusing on the both time frames (present and future), this comprehensive version of the corporate brand constellation shows the six tangential identity types requiring calibration with the covenanted identity. () J. Balmer 2012.

three versions should be deployed so that senior managers can acquire a three dimensional chart of the corporate brand constellation. ${ }^{30}$

- Corporate Brand Being Constellation-Concerned with the identity dimensions of the corporate brand constellation relating to the current time frame: the Actual, $C^{1}$ ommunicated, $C^{2}$ onceived, $C^{3}$ ovenanted, and $C^{4}$ ultural Identities (see Figure 1).

- Corporate Brand Becoming Constellation-Focuses on the identity dimensions of the corporate brand constellation concerned with the future time frame: the Actual, $C^{3}$ ovenanted, $C^{4}$ ultural, Ideal, and Desired Identities (see Figure 2).

- Corporate Brand Bridging Constellation-Relates to the identity dimensions of the corporate brand constellation which embraces both time-frames and, therefore, encompasses all seven identity components: Actual, $C^{l}$ ommunicated, $C^{2}$ onceived, $C^{3}$ ovenanted, $C^{4}$ ultural, Ideal, and Desired Identities (see Figure 3).

See Table 6, which compares the nature of utility of the three approached detailed above.

\section{The REDS ${ }^{2}$ Diagnosis Process}

In operationalizing the $\mathrm{AC}^{4} \mathrm{ID}$ Test framework (in full or in terms of one of its variants) senior managers can be guided by a five-stage approach-the REDS ${ }^{2}$ process: Reveal, Examine, Diagnose, Select, and Strategy. The REDS ${ }^{2}$ process is shown in Table 7. 
TAB LE 6. Comprehending Corporate Brand Being, Becoming, and Bridging

\begin{tabular}{|c|c|c|c|c|}
\hline $\begin{array}{l}\text { Focus: } \\
\text { Corporate } \\
\text { Brand }\end{array}$ & $\begin{array}{l}\text { Time } \\
\text { Frame/s }\end{array}$ & $\begin{array}{l}\text { Nature of } \\
\text { Calibration }\end{array}$ & $\begin{array}{l}\text { Corporate } \\
\text { Brand } \\
\text { Identities } \\
\text { Requiring } \\
\text { Calibration }\end{array}$ & Utility \\
\hline BEING & Present & $\begin{array}{l}\text { Clear: } \\
\text { Alignment with the } \\
\text { covenanted corporate } \\
\text { brand identity }\end{array}$ & $\begin{array}{l}\text { Actual Corporate } \\
\text { Identity, } \\
C^{1} \text { ommunicated/ } \\
C^{2} \text { onceived/ } \\
C^{3} \text { ovenanted/ } \\
C^{4} \text { ultural/ Corporate } \\
\text { Brand Identities }\end{array}$ & $\begin{array}{l}\text { Maps key corporate } \\
\text { brand identity } \\
\text { interfaces which } \\
\text { inform the corporate } \\
\text { brand constellation as } \\
\text { it currently is }\end{array}$ \\
\hline BECOMING & Future & $\begin{array}{l}\text { Complex: Alignment } \\
\text { with the ideal/desired } \\
\text { or covenanted } \\
\text { corporate brand } \\
\text { identity will need to } \\
\text { be ascertained }\end{array}$ & $\begin{array}{l}\text { Actual Corporate } \\
\text { Identity, } C^{3} \text { ovenanted/ } \\
C^{4} \text { ultural/ldeal/ } \\
\text { Desired Corporate } \\
\text { Brand Identities }\end{array}$ & $\begin{array}{l}\text { Maps key corporate } \\
\text { brand identity } \\
\text { interfaces which will } \\
\text { inform the corporate } \\
\text { brand constellation as } \\
\text { it expected to be }\end{array}$ \\
\hline BRIDGING & $\begin{array}{l}\text { Present \& } \\
\text { Future }\end{array}$ & $\begin{array}{l}\text { Complex: Alignment } \\
\text { with the ideal/desired } \\
\text { or covenanted } \\
\text { corporate brand } \\
\text { identity will need to } \\
\text { be ascertained }\end{array}$ & $\begin{array}{l}\text { All corporate brand } \\
\text { identities }\end{array}$ & $\begin{array}{l}\text { Maps key corporate } \\
\text { brand interfaces which } \\
\text { inform the corporate } \\
\text { brand constellation as } \\
\text { it currently is and is } \\
\text { expected to be }\end{array}$ \\
\hline
\end{tabular}

TABLE 7. The REDS² Diagnostic Process

\begin{tabular}{|c|c|c|}
\hline Stage I & $\underline{\mathbf{R}} E \mathrm{EVAL}$ & Identity characteristics \\
\hline Stage 2 & $\underline{E} \times$ AMINE & The interfaces between the covenanted identity and other identities \\
\hline Stage 3 & 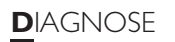 & Identity misalignments and their nature \\
\hline Stage 4 & $\underline{\mathbf{s}}^{\mathbf{l} E L E C T}$ & $\begin{array}{l}\text { Interfaces requiring management intervention. Ascertaining and prioritizing } \\
\text { by considering issues of: urgency, desirability, and feasibility (scenario planning } \\
\text { may be efficacious in terms of prioritization) }\end{array}$ \\
\hline Stage 5 & $\underline{\mathbf{s}^{2}}$ TRATEGY & $\begin{array}{l}\text { Determine the most efficacious and efficient course of action to achieve } \\
\text { alignment. (It is important to establish a standard time frame to effect changes } \\
\text { to the covenanted identity vis-à-vis the ideal and/or the desired identities.) }\end{array}$ \\
\hline
\end{tabular}

Note: For the first articulation of the REDS process, see J.M.T. Balmer, "From the Pentagon: A New Identity Framework," Corporate Reputation Review, 4/I (2001): II-22.

\section{Issues of Misalignment and the Coca-Cola, Hilton, Co-op Bank, and British Monarchy Cases}

The following cases are examples of critical corporate brand misalignments. The examples include iconic brands such as Coca-Cola and Hilton, the ethical Co-op Bank brand, and the centuries-old corporate heritage brand that is the British Monarchy. Misalignments occur not only between different identity types, but also across time 
TAB LE 8. Overview of Misalignments vis-à-vis Coca Cola, Hilton, Co-operative Bank, and The British Monarchy

\begin{tabular}{|c|c|c|}
\hline $\begin{array}{l}\text { Corporate } \\
\text { Brand }\end{array}$ & Misalignments & Explanation \\
\hline Coca-Cola & $\begin{array}{l}\text { Communicated Corporate Brand } \\
\text { Identity } \\
\text { Misaligned with: } \\
\text { The Covenanted Corporate Brand } \\
\text { Identity }\end{array}$ & $\begin{array}{l}\text { Coca-Cola by communicating a product } \\
\text { attribute change failed to take account that } \\
\text { Coca-Cola is a corporate, national, cultural } \\
\text { as well as a product brand (icon). Tampering } \\
\text { with the product was seen by many in the } \\
\text { U.S. as tampering with an emblematic national } \\
\text { and cultural entity. }\end{array}$ \\
\hline Hilton & $\begin{array}{l}\text { Multi-Covenanted Corporate Brand } \\
\text { Identities } \\
\text { Misaligned with: } \\
\text { A Single Conceived Corporate Brand } \\
\text { Identity }\end{array}$ & $\begin{array}{l}\text { Although the public viewed Hilton as a single } \\
\text { brand the two owners of the Hilton had-- } \\
\text { and communicated-two distinct corporate } \\
\text { brand promises. }\end{array}$ \\
\hline $\begin{array}{l}\text { Co-operative } \\
\text { Bank }\end{array}$ & $\begin{array}{l}\text { The Ideal Corporate Brand Identity } \\
\text { Misaligned with: } \\
\text { Covenanted Corporate Brand Identity }\end{array}$ & $\begin{array}{l}\text { The adoption of a new ethical/CSR } \\
\text { positioning for the bank meant that the extant } \\
\text { brand positioning based on innovation } \\
\text { required change. }\end{array}$ \\
\hline $\begin{array}{l}\text { The British } \\
\text { Monarchy }\end{array}$ & $\begin{array}{l}\text { Communicated, and Conceived, } \\
\text { Corporate Brand identities } \\
\text { Misaligned with: } \\
\text { The Ideal \& The Desired Covenanted } \\
\text { corporate brand identities }\end{array}$ & $\begin{array}{l}\text { The King's advisors strategized that the } \\
\text { optimum strategic corporate brand } \\
\text { positioning (ideal corporate brand identity) } \\
\text { for the British Crown should be resolutely } \\
\text { British. The King wished for the same (desired } \\
\text { identity). Existing communications of the } \\
\text { Monarchy (communicated corporate brand } \\
\text { identity) and public perceptions of the Crown } \\
\text { (conceived corporate brand identity) were } \\
\text { ostensibly German in nature. }\end{array}$ \\
\hline
\end{tabular}

as well (as per the becoming and bridging constellations detailed above). In most cases, the identities of the corporate brand constellation should be calibrated with the covenanted corporate brand identity. However, in some instances the corporate brand identity requires change so that it mirrors corporate strategy and/or senior management vision. The case examples of the Co-operative Bank and the British Monarchy are examples of this. The collective insights from these empirical case studies underscore the efficacy of the $\mathrm{AC}^{4} \mathrm{ID}$ Test framework and the identity-based view of corporate brands theoretical approach. It is important to recognize that there are often multiple misalignments at any one point in time. Thus, while reference is made to a particular misalignment in the examples that follow, the reader may very well identify other misalignments and may determine that others are of greater significance. Table 8 details the corporate brand misalignments that have been found to characterize these cases.

\section{Coca-Cola: Communicated Corporate Brand Identity Misaligned with the Covenanted Corporate Brand Identity}

Corporate heritage brands, sometimes, are constants in an ever-changing world and stakeholder attachment to the corporate brand can be very high. 
This brand attachment can also have a highly emotional quality as neurological research has confirmed. ${ }^{31}$ For instance, when Coca-Cola introduced a new taste for the eponymous Coca-Cola beverage brand in 1985 (after extensive market research) and removed the classic formula, there was a hostile-somewhat mystifying-public response. The new product flopped and was eventually removed. In a celebrated volte-face, senior executives quickly reinstated the classic Coca-Cola formula. What went wrong? Senior executives failed to grasp that Coca-Cola was imbibed in two ways: as a much-loved beverage, certainly, but it was also consumed as an iconic corporate brand. The brand meaning of CocaCola was as a powerful symbol of both a place and a people. By altering the taste, senior executives were unwittingly tampering with a cultural and national emblem of the U.S. The removal of the formula was, for many, a de facto form of psychological amputation: Coca-Cola was, and is, a highly meaningful U.S. symbol. The lesson from the Coca-Cola example is that corporate brands can become liabilities when senior executives give insufficient attention to the cultural and national significance of certain brands such as Coca-Cola. In the U.S., emotional ownership of Coca-Cola brand is broad: it resides with the nation and its citizens.

\section{Hilton: Multi-Covenanted Corporate Brand Identities Misaligned with a Single Conceived Corporate Brand Identity}

“Today, a normal guest doesn't know the difference between Hilton Hotel Corporation and Hilton International: they see it as one brand." ${ }^{32}$ This statement, from an interview with a senior Hilton executive, reminds us that from the late 1960s until recently the Hilton hotel brand was under dual ownership and, up until 1997, there was little attempt to strategically coordinate their corporate brand promises and communications. This weakened the value of the brand and caused considerable confusion for customers. For instance, there was not a single reservations system or rewards program. Realizing that a single corporate brand required a seamless strategy for the corporate brand across the two entities, the U.S.-based Hilton Hotel Corporation (HHC) entered into a strategic branding alliance with the UK-based Hilton International (HI). As part of this initiative, a unified worldwide reservations system, a unified loyalty program (HHonors), and a shared corporate communications stratagem (including the shared use of a single brand marque) were adopted. Where there is dual or multiple corporate ownership and use of a corporate brand, there is a strategic imperative to embrace a cross-organizational approach for articulation, communication, maintenance, and management of the corporate brand. Managers need to be reminded that the real value of corporate brands comes from its emotional ownership by customers and the assurance they receive from a corporate brand. ${ }^{33}$

\section{The Co-operative Bank: Ideal Corporate Brand Identity Misaligned with the Covenanted Corporate Brand Identity}

In the latter part of the $20^{\text {th }}$ Century, Britain's Co-operative Bank brand was known for its customer-service ethos and for its innovations in banking services. It was, for instance, a leader in the provision of interest-bearing current accounts. 
However, with financial services deregulation, competition between financial services institutions intensified and the Co-operative Bank's innovations-and a brand promise that emphasized innovation-were no longer a source of sustainable competitive advantage. For instance, competitor financial institutions speedily copied the bank's product improvements. Moreover, the Co-op Bank found the high capital costs of new product launches increasingly prohibitive. As noted by one of the bank's manager, the Co-op was: "Stuck between the big four [banks] and the building societies [mutuals] and lost." ${ }^{34}$ Yet, although the bank contemplated numerous alternatives, finding a strategically sound and durable corporate brand positioning strategy remained elusive. Moreover, the bank's recent brand positioning, pursued during the 1970s, consciously distanced the bank from the blue-collar image of the co-operative movement's brand. During this period, the bank sought to position the bank as a stand-alone brand in its own right. However, this policy militated against bank considering and drawing on its Co-operative provenance. ${ }^{35}$

The appointment of a new Managing Director resulted in a strategic volte-face and he recognized there could be considerable merit in revisiting the bank's co-operative inheritance. It was hoped that the bank's history would divulge key identity attributes that could inform a new corporate identity (one that was strategically sounds and credible). In revisiting the co-operative movement's past, the bank's senior executives re-appraised themselves of their links with the $18^{\text {th }}$ century Rochdale Pioneers who were inspired by the ethos of the social reformer Robert Owen. As an advocate of worker capitalism, Owen established the world's first-ever model cooperative society. However, the bank's senior managers had not appreciated that the Rochdale Pioneers had established for the co-operative movement what today we would characterize as a clear corporate socially responsible (CSR) and ethical remit. Moreover, they realized that these identity attributes had always informed the bank's identity: attributes that were increasingly valued by society at large. Based on this historical research and informed by strategic analysis, a clear ideal corporate brand identity positioning was adopted for the bank. It was a positioning that could be drawn on in articulating a new covenanted identity-the Co-operative Bank as an ethical corporate brand. This was not only strategically sound and sustainable, but unique and an incontrovertible competitive advantage. The existing brand promise that focused on innovation was misaligned with the strategically orientated ideal corporate brand identity (an ethical and CSR brand promise). For this reason a new corporate brand covenant had to mirror the ideal corporate brand identity.

As the bank's CEO noted in 1993, "Given our origins as a part of the cooperative movement and its basic values, it is perhaps not surprising that we should be the first bank to respond to people's growing concerns about the quality of life here and in the rest of the world." ${ }^{36}$ Moreover, the bank's ethical brand identity positively differentiated the institution from other financial institutions: many then, as today, had a lackluster and problematical image. The analysis offered by London's Sunday Times newspaper back in 1991 helps to explain not only why the bank's ethical brand positioning was highly meaningful and, in stakeholder terms, desirable: "Today the banks are what the gas board and unions were in the 1970s and what local authorities still are: self-important jobsworths who delight in concealing their own incompetence behind a mask of arbitrary 
sadism. . . . In marketing terms they have an image problem that places them somewhere between Dr. Hannibal Lecter and Saddam Hussein." ${ }^{37}$

\section{The British Monarchy: Communicated, and Conceived, Corporate Brand Identities Misaligned with the Ideal and the Desired Covenanted Corporate Brand Identities}

The corporate branding credentials of the British Monarchy are impressive by any measure, in the institution is invested with powerful visual and verbal signifiers (the visual symbols of the Crown and royal coats of arms along with verbal signifiers such as Royal, Regius, On Her Majesty's Service). The Monarchy is also engaged in brand endorsement activities. The British postal service is known as The Royal Mail; its navy is known as The Royal Navy; its premier opera venue is known as The Royal Opera House, and some senior Oxford academics are known as Regius (Royal) Professors. Many corporate brands hold Royal Warrants from the Queen and are entitled to emblaze the Royal Coat of Arms and the words "By appointment to Her Majesty the Queen" on their products and corporate premises. $^{38}$ Bacardi-Martini Ltd., Coca-Cola, Ford, Kellogg's, Nestle, Procter and Gable, Rolls-Royce, Sarah Lee, Twining, and Unisys are among the high-profile firms holding Royal Warrants from H.M. Queen Elizabeth II.

Arguably, one of the most successful and extraordinary corporate rebranding initiatives of the last century was the rebranding of the British Monarchy. During the First World War when Britain was at war with Germany, and when the British armed forces were fighting under the banner "For King and Country," all things Teutonic were anathema. Yet, the dynastic name of the British Crown was Saxe-Coburg Gotha. This was a very public reminder that the British monarchy had a strong German provenance and discernable familial links with the German Kaiser. The public referred to King George V as Britain's "German" King and some reasoned that Britain should become a republic. ${ }^{39}$ In 1917, anti-German sentiment came to a head when a German warplane called Gotha G.IV bombed London causing death and destruction. ${ }^{40}$

Senior Buckingham Palace courtiers (by implication, taking an ideal corporate brand identity perspective), along with the King (by inference adopting a desired corporate brand identity perspective), realized the status quo was untenable-and the Crown's position precarious-and were mutually persuaded to implement a series of audacious and adroit strategic brand initiatives. The aim was to eradicate the Crown's Teutonic associations and polish its British identity anchors. In branding parlance, the British Monarchy was to be positioned as a thoroughly and incontrovertibly British corporate heritage brand. The King's confidants were persuaded that the change of corporate brand name should be a key component of the brand repositioning. Out went the German-derived dynastic brand name Saxe-Coburg Gotha and in came the emblematical English brand name of Windsor (the town of Windsor is the site of the centuries-old Windsor Castle, by all accounts the most imposing and historical of all British royal residences). The Windsor brand name, by association, burnished the British provenance on Britain's Royal Family.

The marque still endures and, today, the British Monarch, H.M. Queen Elizabeth II, remains meaningful to many of her 100,000,000 subjects in the 
16 realms where she is Head of State (for example, as Queen of Canada). In addition, Queen Elizabeth enjoys considerable respect among the 1,000,000,000 people and 54 nations comprising the (British) Commonwealth of which she is the titular head. The on-going credibility of this monarchical corporate brand among its vast and global brand community will be all too apparent in 2012 vis-à-vis the Diamond Jubilee celebrations of the Queen's accession to the throne in 1952. The importance of remaining relevant and the need to embrace change emerged as a key theme of our study on monarchies as corporate brands. ${ }^{41}$ The British monarchy, with roots going back over a thousand years, has survived as a corporate brand because it has changed and, by so doing, has remained relevant. $^{42}$

\section{Summary}

This article has detailed three corporate brand essentials that are of critical importance to the strategic management of corporate brands. Firms need to show commitment to the imperatives of custodianship, credibility, and calibration. Custodianship takes account of the strategic significance of successful corporate brands and this explains why corporate brands need to be viewed as an ongoing senior management responsibility. Within the firm, corporate brands are ubiquitous in terms of their importance and potential impact. They serve as a benchmark against which the firm's activities, behaviors, and values can be appraised.

Credibility deals with issues of corporate brand authenticity and saliency. It is a modus vivendi, a way of living the brand. Corporate brand credibility encapsulates the need for the brand promise to be demonstrably bona fide in terms of a firm's activities, purposes, products and services, and behaviors. This also needs to be supported by a corporate marketing ethos and culture (a stakeholder and societal CSR orientation). The credibility criterion obliges managers to ensure the corporate brand covenant is authentic (reflects the firm's identity), believable (reflects the firm's culture), durable (sustainable), profitable (of value to stakeholders), and responsible (meeting the firm's CSR and ethical responsibilities).

Calibration focuses on a modus operandi, a methodology through which corporate brand credibility can be attained and maintained. Calibration is of material significance since it ensures a company brand remains relevant to stakeholders in the present as well as in the future. This article has detailed a new strategic corporate brand framework, the $\mathrm{AC}^{4} \mathrm{ID}$ Test, which is informed by the theoretical notion of identity-based views of corporate brands. As such, account is taken of multiple disciplinary perspectives, time frames, and internal and external organizational aspects. This framework requires managers to ensure dynamic alignment between the seven identities constituting the corporate brand constellation that form the $\mathrm{AC}^{4} \mathrm{ID}$ acronym. Three versions of the framework enable senior executives to ascertain the nature of corporate brand identity alignment in the present (corporate brand being), future (corporate brand becoming), and present and future (corporate brand bridging). The REDS $^{2}$ process details a five-staged process by which the $\mathrm{AC}^{4} \mathrm{ID}$ Test can be operationalized. 


\section{Reflection}

The scrutiny, stewardship, and shaping of the corporate brand needs to be an indelible component of a firm's strategic deliberations. Moreover, senior executives increasingly must demonstrate their connoisseurship of corporate brands and their management. This has come with a growing realization that successful corporate brands are effective in meeting organizational purposes and are effective means of creating both stakeholder and shareholder value. For many firms, it is incontrovertibly the case that corporate brands are their most prized corporate asset.

\section{APPENDIX A}

\section{The New Corporate Brand Architecture and Typology ${ }^{43}$}

While extant brand architecture typologies typically focus on the relationships between product and service brands and the corporation the typology outlined below focuses on the brand relationship between corporations and their subsidiary corporate brands. The typology takes account of brand architecture vis-à-vis franchises, alliances and other multi-organizational/brand phenomena.

\begin{tabular}{|c|c|c|}
\hline $\begin{array}{l}\text { Brand } \\
\text { Architecture } \\
\text { Mode* }\end{array}$ & Explanation & Indicative Examples \\
\hline Monolithic & $\begin{array}{l}\text { The use of a single corporate brand } \\
\text { name and or marque throughout the } \\
\text { firm (at the corporate, divisional levels } \\
\text { and on its products and services). }\end{array}$ & $\mathrm{BBC}$ \\
\hline Endorsed & $\begin{array}{l}\text { The subsidiary company/business unit name } \\
\text { and/or marque additionally make reference } \\
\text { to the holding company's name and/or } \\
\text { marque. (Sometimes this is expressed as } \\
\text { Company Y: Part of the X Group) }\end{array}$ & $\begin{array}{l}\text { Many constituent colleges of London } \\
\text { University use such an endorsed } \\
\text { architecture mode: Royal Holloway } \\
\text { (College) is a case in point. }\end{array}$ \\
\hline Branded & $\begin{array}{l}\text { Stand alone corporate, service or } \\
\text { product brands that make very little or } \\
\text { no visual reference to the corporate/or } \\
\text { holding company brand. }\end{array}$ & $\begin{array}{l}\text { Bentley (makes no reference to its } \\
\text { parent brand: Volkswagen) }\end{array}$ \\
\hline Familial & $\begin{array}{l}\text { Where two or more entities-operating } \\
\text { in the same sector - jointly own/share } \\
\text { the same corporate brand. }\end{array}$ & $\begin{array}{l}\text { The British Monarchy is a prominent } \\
\text { example of this: the British Queen is } \\
\text { also Queen of I } 5 \text { other countries } \\
\text { including Australia, Canada, Jamaica } \\
\text { and New Zealand (One Monarch, } \\
\text { I6 Monarchies). Hilton had a familial } \\
\text { architecture. }\end{array}$ \\
\hline Shared & $\begin{array}{l}\text { Where two or more entities-operating } \\
\text { in different sectors-jointly own/share } \\
\text { the same corporate brand. }\end{array}$ & $\begin{array}{l}\text { Rolls-Royce is: ( } 1 \text { ) a British-owned } \\
\text { aero-engineering business-to-business } \\
\text { brand and ( } 2 \text { ) a company operating in } \\
\text { the business to consumer sector } \\
\text { making luxury cars (the Rolls Royce }\end{array}$ \\
\hline
\end{tabular}




\begin{tabular}{|c|c|c|}
\hline $\begin{array}{l}\text { Brand } \\
\text { Architecture } \\
\text { Mode }\end{array}$ & Explanation & Indicative Examples \\
\hline & & $\begin{array}{l}\text { car marque is owned by the German/ } \\
\text { Bavarian organization BMW). }\end{array}$ \\
\hline Surrogate & $\begin{array}{l}\text { The use/loan of a corporate brand by } \\
\text { one or more companies (via Franchising/ } \\
\text { Licensing or similar instruments). An } \\
\text { organization's products/services use a } \\
\text { corporate brand that is different from } \\
\text { their own. }\end{array}$ & $\begin{array}{l}\text { This is common within the hospitality } \\
\text { sector with well-known brands such as } \\
\text { Intercontinental Hotels, and Marriott } \\
\text { being franchised/licensed to other } \\
\text { organizations. }\end{array}$ \\
\hline Federal & $\begin{array}{l}\text { The creation and multiple ownership of } \\
\text { a corporate brand (companies who } \\
\text { pool resources in order to establish } \\
\text { a new identity/company) }\end{array}$ & $\begin{array}{l}\text { SAS Scandinavian Airways operates } \\
\text { under this structure as does as did } \\
\text { Airbus in former times }\end{array}$ \\
\hline Supra & $\begin{array}{l}\text { A supra-organizational club brand which } \\
\text { espouse common values and qualities } \\
\text { shared by its members }\end{array}$ & $\begin{array}{l}\text { Airline Alliances such as The One World } \\
\text { Alliance and Star Alliance are exemplars } \\
\text { of this. }\end{array}$ \\
\hline Multiplex & $\begin{array}{l}\text { A multi-faced corporate brand that can } \\
\text { be omnipresent in that they can operate } \\
\text { in different industry sectors in certain } \\
\text { national markets. It can have a multiple } \\
\text { owners/multiple franchises/ and can be } \\
\text { present at the corporate, as well as product } \\
\text { and services levels. }\end{array}$ & $\begin{array}{l}\text { The Virgin brand is an excellent } \\
\text { example of this phenomenon and can } \\
\text { be found in the airline, railroad, finance, } \\
\text { cosmetic, soft drink sectors, etc. The } \\
\text { (UK-based) Easy brand (Easy Jet/Easy } \\
\text { Hotels/ Easy Cruise/Easy Car Hire) is } \\
\text { another representative example. }\end{array}$ \\
\hline
\end{tabular}

* Organizations typically use a variety of architecture modes.

Note: Balmer has worked on corporate brand architecture and typology since the late 1990s. The above typology of Balmer appeared in: J.M.T. Balmer and E.R. Gray, "Corporate Brands: What are They? What of Them?" European Journal of Marketing, 37/7-8 (2003): 984.

\section{APPENDIX B \\ Acknowledgements}

The author acknowledges the support and observations of faculty colleagues and postgraduate students at Brunel University (London), Bradford School of Management and Strathclyde University (Scotland) with whom he has shared his insights vis-à-vis the $\mathrm{AC}^{4} \mathrm{ID}$ Test. This article, in part, marshals published insights from a number of collaborative studies and he wishes to acknowledge and thank Professor Stephen A. Greyser (Harvard Business School), Dr. Helen Stuart (Catholic University of Australia), Irene Thomson (Bradford School of Management), Professor Adrian Wilkinson (Griffith University, Australia), and Dr. Mats Urde (Lund University, Sweden). The current $\mathrm{AC}^{4} \mathrm{ID}$ Test had its origins in a major study that the author led in the mid-1990s undertaken at Strathclyde University and he thanks and acknowledges Dr. Guillaume Soenen who assisted him in the early stage of the model's development. He also wishes to thank many of the organizations and senior managers cited in this article for their assistance.

\section{Notes}

1. For indicative examples of the literature on corporate brands/corporate brand management, see J.M.T. Balmer, “Explicating Corporate Brands and their Management: Reflections and 
Directions from 1995," Journal of Brand Management, 18/3 (December 2010): 180-197; K. Punjaisri and A. Wilson, "Internal Branding Process: Key Mechanisms, Outcomes and Moderating Factors," European Journal of Marketing, 45/9-10 (2011): 1521-1538; J.M.T. Balmer, M-N. Liao, and W-Y. Wang, "Corporate Brand Identification and Corporate Brand Management: How Top Business Schools Do It," Journal of General Management, 35/4 (Summer 2010): 77-102; M. Urde, "Uncovering the Corporate Brand's Core Values," Management Decision, 47/4 (2009): 616-638; A. Mukherjee and J.M.T. Balmer, "New Frontiers and Perspectives in Corporate Brand Management: In Search of a Theory," International Studies of Management and Organization, 37/4 (Winter 2007/2008): 3-19; S. Leitch and S. Davenport, "Corporate Brands and Social Brands: Co-Branding GM-Free and UK Supermarkets," International Studies of Management and Organization, 37/4 (Winter 2007/2008): 45-63; J.M.T. Balmer and M.-N. Liao, "Student Corporate Brand Identification: An Exploratory Case Study," Corporate Communications: An International Journal, 12/4 (2007): 356-375; T. Brixendorf and J. Kernstock, "Corporate Behavior vs. Brand Behavior: Towards an Integrated View," Journal of Brand Management, 15/1 (2007): 32-40; T. Abimbola and C. Vallaster, "Brand, Organisational Identity, and Reputation in SMEs: An Overview." Qualitative Market Research, 10 (2007): 341-348; K.L. Keller and D.R. Lehmann, "Brands and Branding: Research Findings and Future Priorities," Marketing Science Institute Special Report, 05-200 (2005); D.A. Aaker, "Leveraging the Corporate Brand," California Management Review, 46/3 (Spring 2004): 6-18; D.B. Holt, J.A. Quelch, and E.L. Taylor, "How Global Brands Compete," Harvard Business Review, (September 2004): 1-9; S. Knox and D. Bickerton, "The Six Conventions of Corporate Branding," European Journal of Marketing, 37/7-8 (2003): 998-1016; M. Schultz and M.J. Hatch, "The Cycles of Corporate Branding," California Management Review, 46/1 (Fall 2003): 6-26; J. Motion, S. Leitch, and R.J. Brodie, "Equity in Corporate Co-Branding: The Case of Adidas and the All Blacks," European Journal of Marketing, 37/7-8 (2003): 1080-1094; S. Leitch and N. Richardson, "Corporate Branding in the New Economy," European Journal of Marketing, 37/7-10 (2003): 1065-1079; M. Urde, "Core Value-Based Corporate Brand Building," European Journal of Marketing, 37/7-8 (2003): 1017-1040; M.J. Hatch and M. Schultz, "Are the Strategic Stars Aligned for your Corporate Brand?" Harvard Business Review, 79/2 (February 2001); D.A. Aaker and E.A. Joachimsthaler, "The Brand Relationship Spectrum: The Key to the Brand Architecture Challenge," California Management Review, $42 / 4$ (Summer 2000) 8-23; J.M.T. Balmer, "The Three Virtues and Seven Deadly Sins of Corporate Brand Management," Journal of General Management, 27/1 (2001): 1-17; S.D. Knox and S. Maklan, Competing on Value: Bridging the Gap Between Brand and Customer Value (London: Financial Times/Pitman Publishing, 1998); J.M.T. Balmer, “Corporate Branding and Connoisseurship," Journal of General Management, $21 / 1$ (Autumn 1995): 24-27.

2. Regarding the adaptation of the economic theory of the resourced-based view of the firm to corporate brands, see J.M.T. Balmer, "A Resource-Based View of the British Monarchy as a Corporate Brand," International Studies of Management and Organization, 37/4 (Winter 2007/ 2008): 20-44; J.M.T. Balmer and E.R. Gray, "Corporate Brands: What are They? What of Them?" European Journal of Marketing, 37/7-8 (2003): 972-997.

3. Regarding the Harley-Davidson corporate brand, see J. Schouten and J. McAlexander, "Subcultures of Consumption: An Ethnography of the New Bikers," Journal of Consumer Research, 22 (1995): 46-61; B. Yates, Outlaw Machine: Harley-Davidson and the Search for the American Soul (New York, NY: Little Brown, 1999).

4. "Sledgehammers and Stunned Fish: Globalisation with Chinese Characteristics Works at both Corporate and National Level," The Economist, October 1, 2011, p. 63.

5. J.M.T. Balmer, “Identity Based Views of the Corporation: Insights from Corporate Identity, Organizational Identity, Social Identity, Visual Identity, Corporate Brand Identity, and Corporate Image," European Journal of Marketing, 42/9-10 (2008): 879-906.

6. D. Holt, How Brands Become Icons (Boston, MA: Harvard Business School Press, 2004), p. 28-35.

7. J.M.T. Balmer and I. Thomson, "The Shared Management and Ownership of Corporate Brands," Journal of General Management, 34/4 (2009): 15-37; Balmer and Gray (2003), op. cit.

8. "A Bigger World," The Economist, September 20, 2008, p. 3.

9. For further information on the Subway corporate brand and franchise, see <www.subway.co. uk/business/franchise/facts_and_history.aspx>, accessed January 26, 2012.

10. "Hotels: Asset-Light or Asset-Right," The Economist, November 13, 2010, pp. 79-80.

11. Balmer (2008), op. cit.

12. For earlier published work on the $\mathrm{AC}^{4} \mathrm{ID}$ Test dating back to the 1990s, see J.M.T. Balmer, and G.B. Soenen, "The ACID Test of Corporate Identity Management," Journal of Marketing Management, 15/1-3 (1999): 69-92; J.M.T. Balmer, "From the Pentagon: A New Identity Frame- 
work," Corporate Reputation Review, 4/1 (2001): 11-22; J.M.T. Balmer and S.A. Greyser, "Managing the Multiple Identities of the Corporation," California Management Review, 44/3 (Spring 2002): 7286; J.M.T. Balmer, "Corporate Brands: A Strategic Management Framework," Bradford University School of Management, Working Paper No. 05/43, 2005; J.M.T. Balmer, H. Stuart, and S.A. Greyser, "Aligning Identity and Strategy: Corporate Branding at British Airways in the Late $20^{\text {th }}$ Century," California Management Review, 51/3 (Spring 2009): 6-23.

13. For an overview of case study research, see K.M. Eisenhardt, "Building Theories from Case Study Research," Academy of Management Review, 14/4 (1989): 532-550; R.E. Stake, The Art of Case Study Research (Thousand Oaks, CA: Sage Publications, 1995); R.K. Yin, Case Study Research: Designs and Methods (Thousand Oaks, CA: Sage, 2003).

14. For an overview of qualitative/inductive research, see A. Bryman, Social Research Methods (Oxford: Oxford University Press, 2008), pp. 139-163; J. Van Maanen, Qualitative Methodology (Thousand Oaks, CA: Sage, 1983).

15. P. Drucker, “The Discipline of Innovation," Harvard Business Review, 63/3 (May/June 1985): 67-72.

16. J. Micklethwait and A. Wooldridge, The Company: A Short History of a Revolutionary Idea (New York, NY: The Modern Library, 2005), p. 133. Note that in recent years, the British Triumph brand has enjoyed something of a renaissance, as has the Harley-Davidson marque in the U.S.

17. T. Marshall, "Ferry Owners Take Blame for Disaster and Admit Error," Los Angeles Times, April 29, 1987, <http://articles.latimes.com/1987-04-29/news/mn-1504_1_townsend-thoresen>, accessed on line June 9, 2011.

18. S. Davoudi, K. Burgess, and A. Edgecliffe-Johnson, "James Murdoch Fights for his Future," The Financial Times, November 10, 2011 , p. 4; "Last of the Moguls," The Economist, July 23, 2011, p. 7; "Great Bad Men as Bosses," The Economist, July 23, 2011, p. 63; B. Fenton, "Murdoch Flies in to Tackle Crisis," The Financial Times, July 9, 201 1, p. 1; G. Parker, "Cameron Feels Heat in the Media Firestorm," The Financial Times, July 9, 2011, p. 3.

19. The Lex Column, "News Corporation," The Financial Times, July 9, 2011, p. 22.

20. For Douglas Hyde's reflections on corporate brands, see D. Hyde, "New Products that Remain True to Core Values," in W. Dauphinais and C. Price, eds., Straight from the CEO (London: Nicholas Brealey Publishing, 1998), p. 304. For an overview of the work of Frank Pick, see C. Wolmar, The Subterranean Railway (London: Atlantic Books, 2005), pp. 254-257, 266-277; J. Simmons and G. Biddle, eds., The Oxford Companion to British Railway History (Oxford: Oxford University Press, 2003), p. 379; A. Forty, Objects of Desire (London: Thames and Hudson, 1992), pp. 222-238; D. Crystal, ed., The Cambridge Biographical Encyclopaedia (Cambridge: Cambridge University Press, 1998), p. 740.

21. W. Isaacson, Steve Jobs (London: Little Brown, 2011); R. Waters, "Generation Jobs," The Financial Times, October 29, 2011 , p. 14; "Insanely Great," The Economist, October 29, 2011, p. 90; "The Magician," The Economist, October 8, 2011, p. 15; “A Genius Departs," The Economist, October 8, 2011, p. 79; "The Book of Jobs," The Economist, January 30, 2011, p. 11.

22. For an overview of organizations as social and political entities, see D. Bach and D.B. Allen, "What Every CEO Needs to Know About Nonmarket Strategy," MIT Sloan Management Review, 51/3 (Spring 2010): 41-50. For an overview of the corporate marketing literature, see J.M.T. Balmer, “Corporate Marketing Myopia and the Inexorable Rise of a Corporate Marketing Logic: Perspectives from Identity-Based Views of the Firm," European Journal of Marketing, 45/9-10 (2011): 1329-1352; E. Karaosmanoglu, A.B.E. Bas, and J. Zhang, "The Role of the Other Customer Effect in Corporate Marketing: Its Impact on Corporate Image and Customer-Company Identification," European Journal of Marketing, 45/9-10 (2011): 1416-1445; D. Hildebrand, S. Sen, and C.B. Bhattacharya, "Corporate Social Responsibility: A Corporate Marketing Perspective," European Journal of Marketing, 45/9-10 (2011): 1353-1364; J.M.T. Balmer, "Corporate Marketing; Apocalypse, Advent and Epiphany," Management Decision, 47/4 (2009): 544-572; J.M.T. Balmer and S.A. Greyser, "Corporate Marketing: Integrating Corporate Identity, Corporate Branding, Corporate Communications, Corporate Image and Corporate Reputation," European Journal of Marketing, 40/7-8 (2006): 730-741; J.M.T. Balmer, "Corporate Identity and the Advent of Corporate Marketing," Journal of Marketing Management, 14/8 (1998): 963-996.

23. The Halifax Building Society quote is from J. Kay, "The Squandered Legacy," The Financial Times Magazine, June 6-7, 2009, p. 35. The Building Society quote is from J. Torley, "They Have Been Arrogant and Reckless," The Times (of London), May 30, 2009, p. 6.

24. Quote from presentation given by Lord Marshall of Knightsbridge, J.M.T. Balmer, and S.A. Greyser at the 9th International Corporate Identity Group Symposium, November 30, 2007. 
25. J.M.T. Balmer, "The BP Deepwater Horizon Debacle and Corporate Brand Exuberance," Journal of Brand Management, 18/2 (October/November 2010): 97-104; J.M.T. Balmer, S.M. Powell, and S.A. Greyser, "Ethical Corporate Marketing. Insights from the BP Deepwater Horizon Catastrophe: The Ethical Brand that Exploded and then Imploded," Journal of Business Ethics, 102/1 (August 2011): 1-14.

26. R. Mason and G. White, "The Spill in the Gulf of Mexico Won't Stop The Deepwater Scramble for Oil," The Daily Telegraph, October 5, 2011.

27. E.H. Edersheim, "BP Culture's Role in the Gulf Oil Crisis," Harvard Business Review blogs, posted on June 8, 2010,<http://blogs.hbr.org/cs/2010/06/the_bp_cultures_role_in_the_gu.html>.

28. Balmer (2007/2008), op. cit.

29. D. Randall, "Oil spill disaster: The guilty parties," The Independent, June 13, 2010.

30. For a discussion of the philosophical and ontological issues relating to being and becoming in branding contexts, see P. Berthon, L. Pitt, M. Parent, and J-P. Berthon, “Aesthetics and Ephemerality: Observing and Preserving the Luxury Brand," California Management Review, 52/1 (Fall 2009): 51.

31. S. McClure, J. Li, D. Tomlin, K.S. Cypert, L.M. Monatague, and P.R. Montague, "Neural Correlates of Behavioral Preference for Culturally Familiar Drinks," Neuron, 44 (2004): 379-387; M. Henderson, "Coke or Pepsi? In fact it's all in the mind," The Times (London), October 14, 2004, p. 25; T. Oliver, The Real Coke, The Real Story (New York, NY: Penguin Books, 1986).

32. Balmer and Thompson (2009), op. cit.

33. Balmer and Thompson (2009), op. cit.

34. A. Wilkinson, "Changing Fortunes of the Co-operative Bank," Journal of Co-operative Studies, 71 (June 1991): 5-10; A. Wilkinson and J.M.T. Balmer, "Corporate and Generic Identities: Lessons from the Co-operative Bank," International Journal of Bank Marketing, 14/4 (1996): 22-35.

35. J. Gardiner and N. Wenborn, ed., The History Today Companion to British History (London: Collins and Brown, 1995), p. 198.

36. The Cooperative Bank, The Co-operative Bank Annual Report, Manchester, England, 1993.

37. B. Appleyard, "The Cooperative Bank," The Sunday Times, June 2, 1991, p. 6.

38. J.M.T. Balmer, "Corporate Heritage Brands and the Precepts of Corporate Heritage Brand Management: Insights from the British Monarchy on the Eve of the Royal Wedding of Prince William and Queen Elizabeth II's Diamond Jubilee (1952-2012)," Journal of Brand Management, 18/3 (2011): 517-544; T. Heald, A Peerage for Trade: A History of the Royal Warrant (London: Royal Warrant Holders Association and Sinclair-Stevenson, 2002), pp. 203-221.

39. J.M.T. Balmer, "Corporate Heritage Identities, Corporate Heritage Brands and the Multiple Heritage Identities of the British Monarchy," European Journal of Marketing, 45/9-10 (2011): 1380-1398; J.M.T. Balmer, "Scrutinizing the British Monarchy: The Corporate Brand that was Shaken, Stirred and Survived," Management Decision, 47/4 (2009): 639-676; Balmer (2007/2008), op. cit.; I. Hayden, Symbol and Privilege: The Ritual Context of British Royalty (Tuscon, AZ: University of Arizona Press, 1987), p. 6.

40. J. Cannon and R. Griffiths, The Oxford Illustrated History of the British Monarchy (Oxford: Oxford University Press, 1998), p. 591; Hayden, op. cit., p. 45.

41. J.M.T. Balmer, S.A. Greyser, and M. Urde, "The Crown as a Corporate Brand: Insights from Monarchies," Journal of Brand Management, 14/1-2 (September 2006): 137-161.

42. This comparison was made in J.M.T. Balmer, "Corporate Identity, Corporate Branding and Corporate Marketing: Seeing Through the Fog," European Journal of Marketing, 35/3-4 (2001): 281; Balmer and Gray (2003), op. cit., p. 981.

43. Balmer and Gray (2003), op. cit.; J.M.T. Balmer and E.R. Gray, "Corporate Identity and Corporate Communications: Creating a Competitive Advantage," Corporate Communications: An International Journal, 4/4 (1999): 171-176.

California Management Review, Vol. 54, No. 3, pp. 6-33. ISSN 0008-1256, eISSN 2162-8564. () 2012 by The Regents of the University of California. All rights reserved. Request permission to photocopy or reproduce article content at the University of California Press's Rights and Permissions website at http://www.ucpressjournals.com/reprintinfo.asp. DOI: 10.1525/cmr.2012.54.3.6. 
Copyright of California Management Review is the property of California Management Review and its content may not be copied or emailed to multiple sites or posted to a listserv without the copyright holder's express written permission. However, users may print, download, or email articles for individual use. 